\title{
A military reform before the battle of Raphia?*
}

\author{
Christelle Fischer-Bovet (Los Angeles) and Willy Clarysse (Leuven)
}

\begin{abstract}
Polybius (V 63-65) describes the reorganization of the Ptolemaic army by genos, by age, and the breaking up of the old regiments before the battle of Raphia (217 BC). By comparing his words with the papyrological sources, it appears that the translation of genos as "nationality" is problematic here and that the eponymous officers, who were military commanders, were replaced by new ones at that time.
\end{abstract}

Keywords: Ptolemaic army, reform, Raphia, eponymous officers, Polybius

When Antiochos III attacked Coele-Syria in 221-219 BC, Agathokles and Sosibios, the chief ministers of Ptolemy IV made preparations for the war, while at the same time negotiating with the Seleucid king in order to gain some time ${ }^{1}$. Establishing themselves in Memphis, they not only assembled in Alexandria soldiers from Egypt's foreign possessions and new mercenaries hired from the Aegean, but they also reorganised the Egyptian army (Plb. V 63-64.2). Condottieri who had served in the Antigonid army, coming straight from Greece, took the troops in hand and drilled them properly (Plb. V 64.3-65). The reorganisation is described

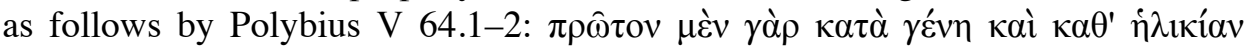

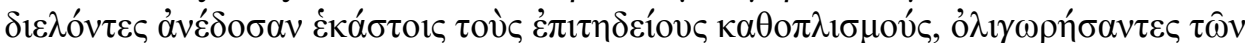

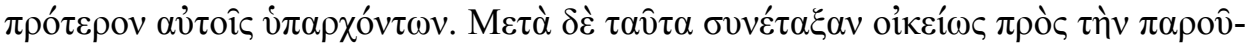

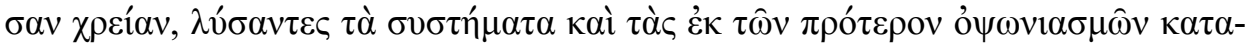
$\gamma \rho \alpha \varphi \alpha ́ c$ (First of all they divided them according to classes ( $\gamma \varepsilon \dot{v} \eta)$ and ages, and provided to each suitable weaponry, taking no account of what they had before. Next they organized them in a way fitting the needs at hand, breaking up the regiments and abolishing the previous paymasters' lists) ${ }^{2}$.

According to Polybius the major overhaul of the Ptolemaic army in 219-218 consists of three elements: 1) organisation by genos, 2) organisation by age and 3 ) the breaking up of the old regiments. One would expect that something of this

\footnotetext{
* An earlier draft of this article was substantially improved thanks to Dorothy Thompson's helpful suggestions.

${ }^{1}$ For recent surveys of the events, see W. Huss, Ägypten in hellenistischer Zeit, Munich, 2001, pp. 386-404 and A. Grainger, The Syrian Wars, Leiden, 2010, pp. 195-218.

2 F. Walbank, Commentary I, p. 589 renders the last words as "the former pay-sheets"; P. Pédech, Polybe (Budé edition 1977), p. 120 translates: "supprimer les rôles des anciennes soldes."
} 
would be visible in the papyrological documentation, but thus far nobody seems to have put Polybius to the test by comparing his words with the documentary evidence.

1) Most translators of Polybius interpret the division by genê as a reorganisation by nationalities or ethnic groups ${ }^{3}$.

There are three problems with this view: first, organisation by ethnic groups is already visible in the papyrological documentation before Raphia; second, Polybius' own description of the division of the troops for their training and tactical use is not solely based on ethnicity; third, genê can have a broader meaning.

First, ethnic grouping in army administration is used already in 232/231 BC, when a hipparchy of the Thessalians and other Greeks (CPR XVIII 10, 1. 197; P.Vindob. ined. 56631, information by B. Kramer) and a hipparchy of "the Persians and of the..." (CPR XVIII 15, 1. 298-9) are found ${ }^{4}$. These were probably longer names for what is elsewhere called the hipparchy of the Thessalians and that of the Persians ${ }^{5}$. In the documentation after Raphia we do not see any major changes. Five ethnic hipparchies are still attested between 222 and c. $170 \mathrm{BC}^{6}$ : Thracians, Mysians, Persians, Thessalians (in one case called "Thessalians and other Greeks", Pros.Ptol. II and VIII 2735-2746) as well as Macedonians (P.Vindob. G 40160, an unpublished petition dated to c. $184 \mathrm{BC})^{7}$. We do not know when this system was created, but ethnic grouping was perhaps already in use before 232/1 BC. In any case, already in 232/231 ethnic hipparchies were open to other groups, as can be seen from names such as "of the Persians and of ...". Moreover, when the ethnic of an individual cavalryman is known, it rarely coincides with the name of the ethnic hipparchy. This happens throughout the given period, from Diphilos, Thracian, of the hipparchy of the Thessalians and other Greeks in 232/1 BC (CPR XVIII 10, 1. 197) to Ptolemarchos, Macedonian, of the hipparchy of the Thessalians and of the other Greeks (PP II/VIII 2743), the last attestation of an ethnic hipparchy in $174 / 3 \mathrm{BC}^{8}$. After the 170 's $\mathrm{BC}$ only the

\footnotetext{
3 Thus H. Drexler, Polybios. Geschichte (Die Bibliothek der alten Welt 1961), p. 478: "nach Herkunft und Alter"; W.R. Paton, Polybius (Loeb edition 1966), p. 159: "they divided them according to their ages and nationalities"; D. Roussel, Polybe. Histoire (Pléiade edition 1970), p. 503: "selon leur âge et leur nationalité d'origine"; P. Pédech, Polybe (Budé edition 1977), p. 120: "classer par pays et par age"; W. Huss, Ägypten in hellenistischer Zeit, p. 393: "nach Herkunft und Alter"; R. Waterfield and B. McGing, Polybius. The Histories (Oxford University Press 2010): "based on ethnicity and age".

${ }^{4}$ For the date of CPR XVIII, see the article below p. 36-42.

${ }^{5}$ For the Thessalians, see M. Launey, Armées, p. 220.

6 Cf. F. Uebel, Die Kleruchen Ägyptens unter den ersten sechs Ptolemäern, Berlin 1968, pp. 379-380 with index, p. 423.

${ }^{7}$ Cf. B. Kramer, CPR XVIII, p. 80, who provided the information about the date.

8 Other examples discussed by F. Uebel, Die Kleruchen, p. 351, n. 5 and Launey, Armées, pp. 220-221, see now Fischer-Bovet, Army and Society in Ptolemaic Egypt, Cambridge, forthcoming, chapter 4; for the abolition of the ethnic hipparchies, see R. Daniel, 'Two Michigan Papyri', ZPE 24 (1977), pp. 75-88.
} 
numbered hipparchies remained; these had already been created around $235 \mathrm{BC}^{9}$. Their number increased from five to ten from the third to the first century BC, probably by incorporating cavalrymen who belonged to the ethnic hipparchies ${ }^{10}$.

Second, when Polybius lists the Greek condottieri training each large section of the army (V 65), he also describes groups according to their provenance: 20,000 Egyptians forming a phalanx and 3,000 Libyans armed in the Macedonian fashion as well as 3,000 Cretans. At first sight this seems to support the common interpretation of genê as ethnic groups. However, in Polybius' account troops of different origin are also grouped together: the cavalry of the guards (Greco-Macedonian settlers) with cavalry from Libya and that enlisted in Egypt (Plb. V 65.5; 82.4) presumably formed the heavy cavalry. Thracians and Galatians (V 65.10; 82.4) both belonged to the light infantry and had a similar type of military equipment ${ }^{11}$. The phalangists were mercenaries recently hired, mercenaries already serving in

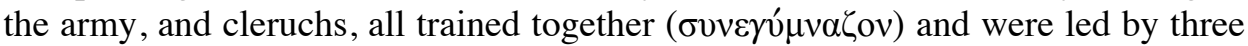
commanders (Plb. V 65.3-4); finally, the royal guard and the 2,000 peltasts constituted particular categories of soldiers rather than purely ethnic groups (Plb. $\mathrm{V}$ 65.5.2) ${ }^{12}$. This organisation coincides with tactical categories on the battlefield (V 82) ${ }^{13}$ and with types of military equipment.

This leads us to our third point. The meaning of $\gamma \varepsilon$ 'vo "ethnic grouping", notably in Polybius, where genos means "class, category, formation" or also "military arm" 14 . Polybius uses the term several times in his description of the Roman army. The selection of a man responsible for the watchword

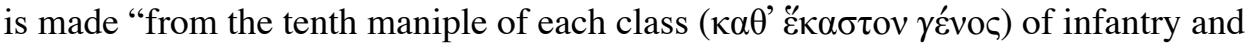
cavalry" (VI 34.8). He previously explains how the new recruits are divided by age in four groups, each category with a specific weaponry ( $\kappa \alpha \theta 0 \pi \lambda \iota \sigma \mu$ ó $\varsigma$ ) to form a legion (VI 21). Ptolemy IV and his ministers may have divided their troops by categories such as heavy and light infantry, heavy and light cavalry, subdivided in their turn in age groups, in order to reorganise the chiliarchies (largest infantry regiments, ca. 1,000 men) and hipparchies (largest cavalry units, ca. 500 men).

To sum up, the interpretation of genos as a category rather than an ethnic group makes Polybius' passage more coherent and avoids a contradiction between Polybius' narrative and the documentary sources; we also know that ethnic grouping was not the essential criterion used by the Ptolemies because chiliarchies, num-

\footnotetext{
${ }^{9}$ Cf. F. Uebel, Die Kleruchen, pp. 379-380.

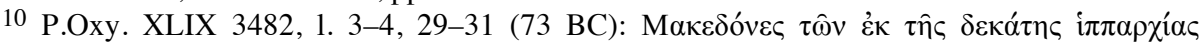

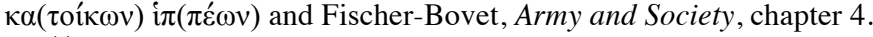

${ }^{11}$ The oval shields used by Thracian light infantry and by the Galatians were very similar, see M. Launey, Armées, p. 533-534, N. Sekunda, 'Military forces', p. 341, and C. Fischer-Bovet, Army and society, chapter 4

12 N. Sekunda, 'Military forces' in P.A.G. Sabin et al. (eds), The Cambridge history of Greek and Roman warfare, vol. I, Cambridge, 2007, p. 339.

${ }^{13}$ For the disposition of the troops at Raphia, see B. Bar-Kochva, The Seleucid army: organization and tactics in the great campaigns, Cambridge, 1976, fig. 8.

${ }^{14}$ Cf. Mauersberger, Polybios-Lexikon I, p. 372-3.
} 
bered hipparchies and even ethnic hipparchies grouped soldiers with different ethnics. Yet, there seems to be no change in the documentation regarding military categories around the battle of Raphia.

2) Beside Polybius' report, only little can be said about age groups in the Ptolemaic army: more than a generation before Raphia some Zenon papyri distinguish between presbyteroi, "veteran soldiers" and neaniskoi "youngsters", but no new categories are known from Philopator's time ${ }^{15}$.

3) What about the "breaking up of the old regiments"? If this happened, it should be visible in our sources, where soldiers are usually identified by their ethnic and their military unit ${ }^{16}$. The unit typically includes the name of the so-called eponymous officer, except for the cavalrymen belonging to ethnic hipparchies, where no eponymous officer is given. These officers belonged to the highest aristocracy, as several of them are eponymous priests or fathers of eponymous priests/priestesses in Alexandria ${ }^{17}$. Traditionally they have been considered military commanders. In the papyrus documentation all eponymous officers were replaced by new ones between 222 BC and the battle of Raphia in 217 BC. This may reflect some military reorganisation.

Since, however, the military function of the eponymous officers has been doubted, we need first to address this issue ${ }^{18}$. Indeed, Oates suggested that the eponymous officers were administrative officials in charge of cleruchic settlements, i.e. involved with the organisation of land distribution among military settlers ${ }^{19}$. His view was supported by Bagnall ${ }^{20}$. There are, however, serious problems with this view and we wish here to argue in favour of the earlier interpretation by considering some of the individuals involved and the role they play in the documentation.

- First, it is unlikely that members of the highest court aristocracy would be mere administrators of land distribution in one or more nomes.

- Second, cleruchs in a single village sometimes belong to completely different companies, with different eponymous officers. This is unlikely if eponymous officers were officials responsible for the distribution of kleroi. It is far less problematic for real officers, who are not concerned by the location of their soldiers' kleroi, since they directly gathered them where and when needed. That

15 Cf. M. Launey, Recherches sur les armées hellénistiques, Paris, 1949, pp. 859-867; F. Uebel, Die Kleruchen, p. 46 n. 5 and 379; B. Kramer, CPR XVIII, p. 79-80.

${ }^{16}$ Cf. F. Uebel, Die Kleruchen, pp. 11-13.

17 Cf. J. IJsewijn, 'Observationes prosopographicae ad sacerdotes eponymos Lagidarum pertinentes', Aegyptus 38 (1958), pp. 159-170; W. Peremans/E. Van 't Dack, 'Notes sur quelques prêtres éponymes d'Egypte ptolémaïque', Historia 8 (1959), pp. 165-173. The father of the condottiere Polykrates of Argos also became eponymous priest in 217 BC, cf. W. Clarysse, 'Two notes on eponymous priests', Enchoria 6 (1976), pp. 1-5.

${ }^{18}$ For a survey of the different views, see Kramer, CPR XVIII, pp. 74-78.

19 J.F. Oates in the introduction to P.Yale I 27.

${ }^{20}$ R.S. Bagnall, 'Some notes on P.Hib. 198', BASP 6 (1969), pp. 73-101, esp. pp. 79-82. 
soldiers of the same troop often have their kleroi in the same environment is of course not a problem even if eponymous officers are indeed military men.

- Third, and most importantly, when something is known about the functions of eponymous officers, these are clearly military:

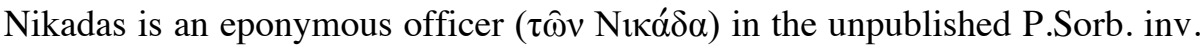
2294 and head of a hipparchia in P.Sorb. I 17 a 6 and b 6f (PP VIII 1959b). Zoilos, a well-known eponymous officer (PP II 1908, see Table 1 below) is

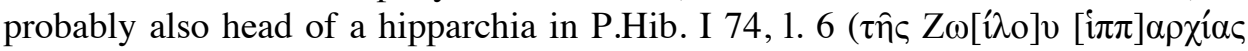

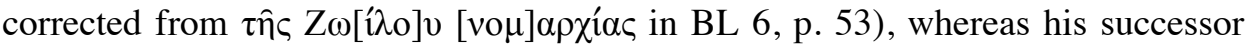
Philon seems to be addressed as i $\pi \pi \alpha ́ \rho \chi \eta \varsigma$ in BGU X 1905²1. Later, under Ptolemy $\mathrm{V}$, the eponymous commander Aristonikos is both hipparch and admiral (PP II/VIII $1853=2194=$ PP VI 14895, $15187=$ Mooren, Prosopography, no 191 $)^{22}$.

Pythangelos, Lichas and Eumenes are attested in Strabo as leaders of elephant hunting expeditions in the South during the reign of Euergetes and clearly occupied a military function around the time they are attested as eponymous officers ${ }^{23}$ : among the men of Pythangelos are cavalry officers (epilarchai and epilochagoi), among those of Lichas are cavalry officers (an ilarchês and a dekanikos) and an infantry officer (pentakosiarchos) and among those of Eumenes is a cavalry officer (lochagos).

Moreover, in some cases soldiers appear in the documentation as "not yet

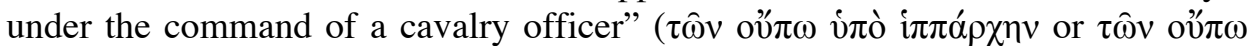
$\dot{v} \varphi$ ' $\gamma \varepsilon \mu \operatorname{ó} \alpha)$ even though they were already attached to an hipparchy ${ }^{24}$. Here again the name following $\tau \hat{\omega} v$ is that of a cavalry or infantry officer, not an official in charge of cleruchic land; some eponymous officers are even at the head of both cavalry and infantry officers, such as Lichas mentioned above and Eteoneus (PP II/VIII 1902). Apparently the titles chiliarch and/or hipparch were used on more than one level. Some eponyms had chiliarchs and/or hipparchs below them but we do not have evidence that they themselves held a different title ${ }^{25}$.

${ }^{21}$ S. Pfeiffer, 'Der eponyme Offizier Tubias: ein lokaler Vertreter der ptolemäischen Herrschaft in Transjordanien', APF 56 (2010), p. 250, n. 39 (accepting the view of Bagnall); Uebel, Die Kleruchen, p. 135 and 309.

${ }^{22} \mathrm{He}$ is eponymous priest in 187/6 BC (PP III 5022); Polybius makes clear that Aristonikos was a military man at the top of the hierarchy by mentioning his role in recruiting mercenaries at the end of the Great Revolt (Plb. XXII 17.6), and giving a short portrait of this childhood friend of the king, born to be a soldier (Plb. XXII 22).

23 E.g. Eumenes (PP II and VIII 1899 = 4420); Lichas (PP II 1938 = 4422); Pythangelos (Pros.Ptol. II $1998=4425$ ).

${ }^{24}$ E.g. Kramer, CPR XIII 18, 1. 382-3, with pp. 64-65, 77-78: she suggests that in this context a hêgemôn may be a cavalry rather than an infantry officer, see also PP II introduction, p. XXV and BGU VI 1258a, 1. 10 "hêgemôn and hipparchês".

25 In the second century, though, at least three eponymous officers are also territorial governors (one of the meanings of the word stratêgos): Boethos (PP II/VIII $1869=$ Mooren no 053), Lochos (PP II/VIII $1940=$ Mooren no 055) and Hippalos (PP II/VIII $1919=$ Mooren no 043), see also Bagnall, BASP 6 (1969), pp. 80-81 for the first two; both Lochos and Hippalos head a hêgemonia. At that time the soldiers of Chomenis (PP II/VIII $2121=2047=$ Mooren 0213), commander 
If it is accepted that eponymous officers were military officers at the top of the hierarchy, we may now examine whether any changes took place at their level around the time of the Fourth Syrian War. On the basis of the list of eponymous officers in Pros.Ptol. II and VIII 1825-2035 (including some addenda and some corrections of the dates) we have constructed three tables of all persons of that rank who occur more than once and in different years in the period 240-210 BC and the periods preceding and following 26 .

Table 1: Before 240 BC

\begin{tabular}{|l|l|l|l|}
\hline PPt & name & $\mathbf{2 4 0}+$ before & Place \\
\hline 1828 & Aetos & $245 / 4 \& 242 / 1$ & Arsinoite \\
\hline 1830 & Alkippos & $252 / 1 \& 244 / 3$ & Arsinoite? \\
\hline 1841 & Antiochos & $258 / 7$ till $243 / 2$ & Oxy + Arsinoite \\
\hline 2009 & Telestes & $271 / 0$ till 241 & Arsinoite? \\
\hline 2015 & Philagros & 268 till 244 & Oxy \\
\hline
\end{tabular}

Table 2: Between 240 and $227 \mathrm{BC}$

Table 2a

(e.g. year 239 BC represents year 239/8 BC etc.)

\begin{tabular}{|l|l|c|c|c|c|c|c|c|c|c|c|}
\hline PPt & name & $\mathbf{2 4 0}+$ before & $\mathbf{2 3 9}$ & $\mathbf{2 3 8}$ & $\mathbf{2 3 7}$ & $\mathbf{2 3 6}$ & $\mathbf{2 3 5}$ & $\mathbf{2 3 4}$ & $\mathbf{2 3 3}$ & $\mathbf{2 3 2}$ & $\mathbf{2 3 1}$ \\
\hline 1835 & Andriskos & & & $\mathbf{x}$ & & $\mathbf{x}$ & & & & $\mathbf{C}$ & \\
\hline 1872 & Damon & & & $\mathbf{x}$ & & $\mathbf{x}$ & & & & & \\
\hline 1902 & Eteoneus & $\mathbf{x}$ & & & & $\mathbf{x}$ & & & & & \\
\hline 1908 & Zoilos & $\mathbf{O}$ & $\mathbf{O}$ & & & & & & & & $\mathbf{x}$ \\
\hline 1921 & Hippokrates & & & $\mathbf{x}$ & & $\mathbf{x}$ & & & & $\mathbf{C}$ & \\
\hline 1932 & Krateros & & & & & & & $\mathbf{x}$ & & & \\
\hline 1938 & Lichas & & & $\mathbf{x}$ & & & $\mathbf{x}$ & & & & \\
\hline 1949 & Menelaos & $\mathbf{x}$ & & & & $\mathbf{x}$ & & & & & \\
\hline 1961 & Nikanor & $\mathbf{x}$ & & $\mathbf{x}$ & & & & & & $\mathbf{C}$ & \\
\hline 1985 & Ptolemaios s. & $\mathbf{x}$ & & $\mathbf{x}$ & & & & & & $\mathbf{C}$ & \\
\hline 1987 & Eteoneus & & & & & & & & & & \\
\hline 1998 & Ptolemaios s. & & & & & $\mathbf{x}$ & & & & $\mathbf{C}$ & \\
\hline 2019 & Phithangelos & & & $\mathbf{x}$ & & $\mathbf{x}$ & & & & & \\
\hline
\end{tabular}

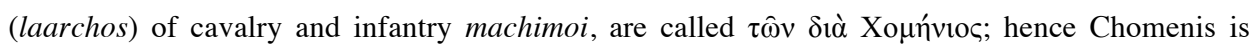
considered an eponymous officer in the Prosopographia Ptolemaica.

26 An eponymous officer Antiochos is attested from 262 to 243 (Pros.Ptol. VIII 1841). A homonymous officer is found in a document of 210/209, published in ZPE 132 (2003), p. 228, but the editor rightly considers him a different person. 
Table 2b

\begin{tabular}{|l|l|l|l|l|l|l|l|l|l|l|l|l|}
\hline PPt & name & $\mathbf{2 3 0}$ & $\mathbf{2 2 9}$ & $\mathbf{2 2 8}$ & $\mathbf{2 2 7}$ & $\mathbf{2 2 6}$ & $\mathbf{2 2 5}$ & $\mathbf{2 2 4}$ & $\mathbf{2 2 3}$ & $\mathbf{2 2 2}$ & $\mathbf{2 2 1}$ & $\mathbf{2 2 0}$ \\
\hline 1835 & Andriskos & & & & & $\mathbf{x}$ & & & $\mathbf{x}$ & & & \\
\hline 1872 & Damon & & & & & & & & & & & \\
\hline 1902 & Eteoneus & & & & $\mathbf{x}$ & & & & $\mathbf{x}$ & & $\mathbf{x}$ & \\
\hline 1908 & Zoilos & $\mathbf{x}$ & & $\mathbf{x}$ & & & & & & & & \\
\hline 1921 & Hippokrates & & & & & $\mathbf{x}$ & & $\mathbf{x}$ & & & & \\
\hline 1932 & Krateros & $\mathbf{x}$ & & & & & & & & & & \\
\hline 1938 & Lichas & & & & & & & & & & & \\
\hline 1949 & Menelaos & & & & & & & & $\mathbf{x}$ & & & \\
\hline 1961 & Nikanor & & & & & & & & & & & \\
\hline 1985 & $\begin{array}{l}\text { Ptolemaios s. } \\
\text { Eteoneus }\end{array}$ & & & & & & & $\mathbf{x}$ & $\mathbf{x}$ & & & \\
\hline
\end{tabular}

Table 2c

\begin{tabular}{|l|l|l|l|l|l|l|l|l|l|l|l|}
\hline PPt & name & $\mathbf{2 1 9}$ & $\mathbf{2 1 8}$ & $\mathbf{2 1 7}$ & $\mathbf{2 1 6}$ & $\mathbf{2 1 5}$ & $\mathbf{2 1 4}$ & $\mathbf{2 1 3}$ & $\mathbf{2 1 2}$ & $\mathbf{2 1 1}$ & $\mathbf{2 1 0}+\mathbf{l a t e r}$ \\
\hline 1835 & Andriskos & & & & & & & & & & \\
\hline 1872 & Damon & & & & & & & & & & \\
\hline 1902 & Eteoneus & & & & & & & & & & \\
\hline 1908 & Zoilos & & & & & & & & & & \\
\hline 1921 & Hippokrates & & & & & & & & & & \\
\hline 1932 & Krateros & & & & & & & & & & \\
\hline 1938 & Lichas & & & & & & & & & & \\
\hline 1949 & Menelaos & & & & & & & & & & \\
\hline 1961 & Nikanor & & & & & & & & & & \\
\hline 1985 & $\begin{array}{l}\text { Ptolemaios s. } \\
\text { Eteoneus }\end{array}$ & $\mathbf{x}$ & & & & & & & & & \\
\hline
\end{tabular}

Table 3: After 210 BC until the 140s BC

\begin{tabular}{|l|l|l|l|}
\hline PPt & name & $\mathbf{2 1 0}+$ later & Place \\
\hline 1870 & Galestes & 180 till 154 & Arsinoite \\
\hline 1874 & Dexilaos or Dexeilaos & 158 till 156 & Memphis \\
\hline 1881 & Diodotos & 150 till $141 / 0$ & Pathyrite \\
\hline 1919 & Hippalos & 182 till 173 & Arsinoite + Thebaid \\
\hline 1946 & Maraios & 210 till 208 & Arsinoite \\
\hline 1947 & Ma... & 177 till 173 & Arsinoite \\
\hline 1962 & Nikanor & 184 till 160 & Pathyrite \\
\hline 1980 & Polycrates & 162 till 157 & Arsinoite \\
\hline 2020 & Phyleus & 201 till $198 / 7$ & Arsinoite \\
\hline
\end{tabular}


Table 2a-c shows that in the Arsinoite nome references all end in the years preceding the battle of Raphia (June 22, 217 BC): Hippokrates is last attested in March 223 BC, Andriskos, Menelaos and Pythangelos in 223/2 BC, Eteoneus in 221/0 BC. Only Ptolemaios son of Eteoneus and Ptolemaios son of Nautas go on until year 4 (January 218 BC) and 5 (April 217 BC) ${ }^{27}$ of Ptolemy IV. The above table also supports Kramer's date under Ptolemy III for the contracts in CPR XVIII, against the lower date proposed by Maresch ${ }^{28}$, which results in very long tenures for five eponymous officers.

We have excluded from our table the reference to Hippokrates in P.Petrie II 47 (= III 55b). This text is dated with certainty to $209 \mathrm{BC}$, but for the name of the eponymous officer only the ending [ - - ] $\rho \alpha \tau \eta \varsigma$ is preserved. The supplement ['I $\pi \pi \mathrm{o}] \kappa \rho \alpha ́ \tau \eta\rceil$, first suggested by Wilcken in P.Petrie III, p. 161, has been generally accepted (Uebel, Die Kleruchen, no. 110; PP X E 600), but is in fact purely hypothetical. Greek personal names ending in -krates are common (three examples already among the eponymous officers) and it is not even excluded that this company was headed by the famous [Poly]krates, one of the heroes of Raphia (Plb V 65.5). It is preferable, however, not to propose a supplement here.

The end date of Ptolemaios son of Nautas needs some justification, as a later date was proposed for him in P.Heid. VI 383; we have discussed this complicated case in a separate article below, p. 36-42.

A similar change occurs at about the same time in the Oxyrhynchite nome. Zoilos, the only eponymous officer for this nome is mentioned in texts from 263 to 228 BC (Pros.Ptol. VIII 1908). He is replaced by Philon (Pros.Ptol. VIII 2019) between 228 (P.Hib. I 105; year 19 Pauni $28=12$ August 228) and 17 Dec. 223 BC (SB III 6281)29. As Philon is attested from 223 BC (SB III 6281) until 200/199 BC (BGU X 1956, [1.6]?), he would be of the earliest new men selected during these years of reform.

To sum up, papyrological sources from these two nomes show a change among the individuals at the top of the military hierarchy. Even if this perhaps happened because of their age, the hiring of the new men listed by Polybius was made easier or necessary. However, because we cannot identify changes in the functions of these military officers in the papyri, the reorganisation does not appear to have been as radical as Polybius suggests. Since his descriptions of the whole army in training and on the battlefield at Raphia are the only ones we have for the Ptolemaic army, it is not possible to evaluate how the division of the troops attributed to each condottiere was different from before. Thus the breaking up of the old regiments is not visible, except perhaps for one aspect related to the numbered hipparchies: before Raphia, the competence of the eponymous officers was not

\footnotetext{
${ }^{27}$ Reference for April 217 BC is SB XX 15068.

28 K. Maresch, Bronze und Silber, p. 77-81. This redating was convincingly rejected by Kramer on prosopographical grounds (see BL 11, p. 73).

${ }^{29}$ For the date of the change, see Uebel, Die Kleruchen, p. 309 n. 5; A. Martin, 'Eupolis l'Athénien', in Proc. XIXth congress of Papyrology II, Cairo 1992, pp. 25-36, esp. pp. 29-30, where he suggests that Zoilos and his successor Philon may be father and son.
} 
always limited to one numbered hipparchy, since some eponymous officers can be linked with more than one hipparchy ${ }^{30}$, and on the other hand, soldiers of a single hipparchy could be registered under different eponymous officers ${ }^{31}$. Hence different squadrons of a same hipparchy might have been attached to different eponymous officers. After Raphia there are no such cases, but the sources concerning the eponymous officers are also scarcer ${ }^{32}$.

\section{Conclusion}

Hints of a reform around the time of Raphia are not related to ethnicity as the Ptolemies partially used ethnic grouping both before and after; clear changes are the disappearance of ethnic hipparchies by the late 170s; in addition, a reorganization of the infantry regiment took place in the $160 \mathrm{~s} \mathrm{BC}^{33}$. Did Polybius attribute changes that occurred between ca. 220 and ca. 160 according to papyrological sources to the years just before Raphia, thus compressing different events or decisions into one single moment? ${ }^{34}$

The only element of the reform of the army mentioned by Polybius which is visible in the papyrological material is the change of the army command in the years 222-217 BC, and this change spread over several years. After Raphia the names of the eponymous officers are all different (with the exception of Philon in the Oxyrhynchite nome). The names mentioned in Polybius do not appear in the documentary sources, except for Ptolemaios son of Thraseas (PP II $2174=$ VI 15236) who probably deserted in $218 \mathrm{BC}^{35}$ and perhaps Polykrates (read as Hippo]kratês, see above, PP II 1921). Most eponymous officers for whom we have more than one date after Raphia were active in the second century BC (see table 3). Some were descendants of the commanders hired for Raphia: Polykrates, archisomatophulax and eponymous commander in the 160s-150s (PP II/VIII 1980 and 4312) was certainly a grandson of the Polykrates in charge of 3,000 cavalrymen at Raphia (Plb. V 65.5); other eponymous officers simply belonged to

\footnotetext{
${ }^{30}$ Hippokrates (PP II 1921) is attested for the 2nd, 3rd and 5th hipparchies, Ptolemaios son Eteoneus (PP II 1985) for the 2nd and 5th hipparchies, Andriskos (PP II 1835) and Ptolemaios son of Nautas (PP II 1987) for the 3rd and 5th hipparchies.

${ }^{31}$ For the 5th hipparchy four different eponymous commanders function more or less simultaneously Hippokrates, Andriskos, Ptolemaios son of Eteoneus and Ptolemaios son of Nautas, see the list in B. Kramer in CPR XVIII, p. 64-65; for the 4th hipparchy, see Androniskos and Menelaos (PP II 1949) in 223/2 BC; for the 2nd hipparchy, see Ptolemaios son of Eteoneus and Hippokrates in 223.

32 See the list of cavalrymen in the numbered hipparchies in PP II/VIII 2747-2846.

${ }^{33}$ N. Sekunda, Hellenistic infantry reform in the 160's BC, Oficyna Naukowa, 2001; K. Vandorpe, 'The Ptolemaic army in Upper Egypt', in A.-E. Véisse et al (eds.) L'armée en Égypte aux époques saïte, ptolémaïque et romaine, Geneva, forthcoming; Fischer-Bovet, Army and society, chapter 4.

${ }^{34}$ For a gradual reform of the cavalry, see C. Armoni, 'Hebdomekontaruroi in numerierten Hipparchien: SB XXII 15213', ZPE 137 (2001), pp. 237-39.

${ }^{35}$ Cf. OGIS I 230 = SEG 49.2457 and M. Launey, Armées, 187.
} 
the next generation of the same families; see Antiochos (n. 19) and Automedon in a new text in the Trier collection ${ }^{36}$.

${ }^{36}$ D. Hagedorn/B. Kramer, Honi soit qui mal y pense. Studien zum pharaonischen, griechischrömischen und spätantiken Ägypten zu Ehren von Heinz-Josef Thissen, Orientalia Lovaniensia Analecta 194, Leuven 2010, pp. 219-232, date the text to 183 BC. The grandfather (?) Automedon is eponymous officer in $252 \mathrm{BC}$ (PP II 1864). 